\title{
Suradljivost adolescenata u psihijatrijskom liječenju
}

\section{Adolescent compliance in psychiatric treatment}

\author{
Kristina Franjićc ${ }^{*}$, Eduard Oštarijaš², Ana Kaštelan ${ }^{3}$
}

${ }^{1}$ Zavod za hitnu medicinu Primorsko-goranske županije

${ }^{2}$ Medicinski fakultet Sveučilišta u Rijeci

${ }^{3}$ Katedra za psihijatriju i psihološku medicinu, Medicinski fakultet Sveučilišta u Rijeci

\section{"Dopisni autor:}

Kristina Franjić, dr. med.

Zavod za hitnu medicinu Primorskogoranske županije

Franje Čandeka 6/A, 51000 Rijeka

e-mail: kristina.franjic4@gmail.com
Sažetak. Suradljivost (engl. compliance) je pojam koji označava u kojoj mjeri pacijent provodi upute o liječenju koje mu je dao liječnik. Loša suradnja ugrožava pacijentovo zdravlje i život, a smanjuje i učinkovitost cjelokupnog zdravstvenog sustava. Rezultati istraživanja jako variraju, kako za psihijatrijske, tako i za ostale pacijente. Svrha rada jest dati pregled znanstvene i stručne literature na temu suradljivosti adolescenata u psihijatrijskom liječenju. Nema naznaka za postojanje razlike u suradnji između adolescenata $\mathrm{i}$ odraslih; izuzetak su adolescenti liječeni od prve psihotične epizode koji bolje surađuju od odraslih s istom dijagnozom. Do sada nije potvrđeno da sociodemografski čimbenici utječu na suradljivost adolescenata.

Ključne riječi: adherencija; adolescencija; psihijatrija; suradljivost

Abstract. Compliance is a term that indicates to what extent the patient follows the medical instructions. Poor compliance reduces treatment efficiency and the efficiency of the overall health system. Research results vary widely, both for psychiatric patients and other patients. The purpose of this paper is to review available literature on adolescent's compliance to the psychiatric treatment. There is no indication of differences in adolescent or adult compliance levels, with one exception: adolescent treated for the first psychotic episode cooperate better than adults with the same diagnosis. So far it has not been confirmed that sociodemographic factors affect adolescent's compliance.

Key words: adherence; adolescent; compliance; psychiatry 


\section{UVOD}

Suradljivost je pojam koji označava u kojoj mjeri pacijent provodi upute o liječenju koje mu je dao liječnik ${ }^{1}$. Suradljivost (engl. compliance) je u engleskom jeziku riječ s negativnim konotacijama i implicira popustljivost ili pokoravanje. Suradljiv pacijent poslušno slijedi liječnikove upute i ima pasivnu ulogu u liječenju ${ }^{2}$. Suvremena medicina od pacijenata traži aktivnu i odgovornu ulogu u liječenju i tako nastaju novi koncepti suradnje: adherencija, podudarnost i ustrajnost.

Adherenciju (engl. adherence) Svjetska zdravstvena organizacija (SZO) definira kao stupanj do kojeg se pacijentovo ponašanje, u obliku uzimanja lijekova, pridržavanja dijetnih režima ili promjena životnog stila, slaže s preporukama zdravstvenog djelatnika ${ }^{3}$. Adherencija označava pridržavanje, privrženost ili odanost liječenju ili lijeku. Pacijent je aktivni sudionik, pacijent i liječnik djeluju zajedno u cilju poboljšanja pacijentova zdravlja ${ }^{4}$. Istraživanja suradljivosti najčešće prate adherenciju u uzimanju lijekova.

U novijoj literaturi nalazimo pojam podudarnost (engl. concordance) koji podrazumijeva da su liječnik i pacijent potpuno usuglašeni oko terapijskog plana. Kraljevsko farmaceutsko društvo Velike Britanije (1997.) predložilo je da se pojmovi suradljivost $i$ adherencija potpuno zamijene pojmom podudarnost jer se time naglašava pacijentova suglasnost u liječenju ${ }^{5}$.

Adherencija se danas promatra kao proces koji se sastoji od inicijacije, implementacije i prestanka uzimanja lijeka. Inicijacija je trenutak u kojem se uzima prva doza lijeka. Implementacija je definirana kao stupanj do kojeg stvarno uzimanje lijeka odgovara propisanom režimu doziranja. Prestanak uzimanja lijeka označuje kraj liječenja, tj. kad je izostavljena doza lijeka nakon koje pacijent više ne uzima taj lijek. Ustrajnost ili upornost (engl. persistence) je razdoblje između inicijacije i posljednje doze, razdoblje tijekom kojeg je pacijent uzimao lijek u skladu s preporukom ${ }^{6}$.

Neadekvatna suradnja pacijenata smanjuje kliničku korist liječenja i sveukupan uspjeh zdravstvenog sustava ${ }^{3}$. Procijenjeno je da se u SAD-u oko $50 \%$ propisanih lijekova ne uzima na propisan način, dok otprilike trećina pacijenata uopće ne uzme propisane lijekove ${ }^{6}$. Nesuradljivost poveća- va rizik od komplikacija, hospitalizacija i smrtnih ishoda, što predstavlja i velik ekonomski teret za zajednicu ${ }^{6}$. Čimbenici koji utječu na suradljivost svih pacijenata pri uzimanju lijekova mogu se podijeliti na: socioekonomske čimbenike, čimbenike povezane s organizacijom zdravstvene skrbi, obilježja samog pacijenta, obilježja bolesti i obilježja propisanog lijeka ${ }^{7}$. Intervencije za poboljšanje suradljivosti imaju veći utjecaj na zdravlje populacije nego bilo koje druge intervencije u zdravstvu ${ }^{3,8}$.

Intervencije za poboljšanje suradljivosti imaju veći utjecaj na zdravlje populacije nego bilo koje druge intervencije u zdravstvu.

Suradljivost psihijatrijskih pacijenata uobičajen je problem u psihijatrijskoj praksi ${ }^{9}$. Prema istraživanju Blondiauxa i sur. (1994.) nesuradljivost zahvaća 15 - $25 \%$ hospitaliziranih i $50 \%$ ambulantnih psihijatrijskih pacijenata; $20 \%$ pacijenata nikad ne preuzme lijekove, a $30-50 \%$ podignutih lijekova ne konzumiraju ${ }^{10}$. Folnegović-Šmalc u svom stručnom prikazu o suradljivosti psihijatrijskih pacijenata opisuje niz čimbenika koji utječu na suradnju: vrsta psihičkog poremećaja (dijagnoza), faza bolesti, struktura osobnosti pacijenta, mogućnost pacijenta da spozna nužnost liječenja (uvid), obitelj pacijenta, liječnici koji propisuju lijek, članovi terapijskog tima i ostali pacijenti ${ }^{11}$. Velik problem istraživanja suradljivosti predstavlja neujednačenost metodologije i nedostatak zlatnog standarda u mjerenju suradljivosti ${ }^{12}$. Metode mjerenja mogu biti direktne ili indirektne. Direktne metode su uzimanje lijeka pod nadzorom, mjerenje koncentracije lijeka ili metabolita u krvi, urinu ili slini te mjerenje bioloških markera u krvi. Indirektne metode su pacijentov dnevnik, upitnici, mjerenje realizacije recepta, mjerenje kliničkog odgovora na terapiju, brojenje preostalih tableta i korištenje elektroničkih monitora. U istraživanjima se savjetuje koristiti kombinaciju više metoda istovremeno ${ }^{7,13}$.

Suradnja adolescenata u liječenju kroničnih bolesti varira od $10 \%$ do $89 \%$ i taj se podatak ne razlikuje bitno od varijacija uočenih u drugim populacijama ${ }^{14}$. Od adolescenta se očekuje da za 
svoje zdravlje preuzimaju sve veću odgovornost i za većinu je ovo postupan, progresivan proces. Adolescenti, kao i odrasli, bolje surađuju pri liječenju ako bolest ima neposredne i potencijalno ozbiljne posljedice, a slabije surađuju ako se radi o preporukama koje imaju manje očitu korist ili ometaju njihov životni stil ${ }^{14}$.

Taddeo i sur. (2008.) u svom pregledu objašnjavaju da uzroci loše suradnje adolescenata mogu biti posljedica psiholoških fenomena tipičnih za tu razvojnu fazu ${ }^{14}$. Nesuradljivost može biti posljedica adolescentova osjećaja da je neranjiv i svemoćan.

Pozitivni učinci psihofarmaka koje adolescenti navode su bolja koncentracija, bolji školski ili akademski uspjeh, bolja samokontrola i više dobrih odnosa s drugim osobama.

Takav grandiozan doživljaj sebe posljedica je negacije vlastite smrtnosti koju adolescent tek mora prihvatiti i ugraditi u svoju osobnost. „Svemoćni“ adolescent negira da je bolestan, pa tako može i odbiti liječenje. Nesuradljivost može biti shvaćena i kao potreba za testiranjem granica. Adolescent svojim ponašanjem provjerava izdržljivost i sposobnost svog tijela i uma, a također testira što mu je dozvoljeno činiti unutar obiteljskih i drugih bliskih odnosa ${ }^{14,15}$. Zbog testiranja granica može odbiti liječenje ili oscilirati u suradnji ${ }^{14}$. Odbijanje lijekova i izbjegavanje pregleda mogu predstavljati pokušaj uspostavljanja kontrole nad svojim životom, jer adolescent doživljava da je bolest preuzela kontrolu nad njim. Osnovna zadaća adolescencije je potraga za vlastitim identitetom. Oboljeli adolescenti imaju znatno teži zadatak jer moraju u svoju osobnost inkorporirati bolest, a loša suradnja može biti posljedica zastoja u tom procesu. Prihvaćanje od strane vršnjaka izrazito je važno adolescentima, stoga mišljenje vršnjaka može utjecati na suradljivost. Primjer je izbjegavanje ili skrivanje liječenja zbog adolescentove želje da ga vršnjaci prihvate. Adolescenti teže nego odrasli provode preventivne mjere (npr. dijete, vježbanje), jer još nemaju potpuno razvijene kognitivne vještine procjene rizika, kontrole impulsa, planiranja i organiziranja aktivnosti ${ }^{14}$. Taddeo i sur. u zaključku svog pregleda izdvajaju ove pozitivne čimbenike koji utječu na suradljivost: dobro funkcioniranje obitelji, uvjerenje roditelja u ozbiljnost bolesti, postojanje bliskih prijatelja, lijekovi koji brzo djeluju, efikasno liječenje i empatija liječnika. Kao negativne čimbenike izdvaja: stariju dob adolescenta, psihijatrijske ili psihološke smetnje, obiteljske sukobe ili socijalne probleme, psihijatrijske ili psihološke smetnje roditelja ili skrbnika, nuspojave lijekova, složeno doziranje te negacija bolesti ${ }^{14}$.

SURADLJIVOST ADOLESCENATA U PSIHIJATRIJSKOM LIJEČENJU

Adolescenti, psihijatrijski pacijenti, posebno su zahtjevna skupina pacijenata za postizanje dobre suradljivosti. Najčešće roditelji, skrbnici ili liječnici nagovaraju ili primoravaju adolescenta da uzima lijekove ${ }^{16}$. Kao maloljetnici nemaju pravo pristanka, što znači da ne mogu sami prihvatiti ili odbiti liječenje. Zato Moses (2011.) uvodi pojam predanosti liječenju (engl. commitment) koju definira kao pacijentovu namjeru nastavljanja liječenja kada ne bi bilo utjecaja ili pritiska okoline ${ }^{16}$. Istraživanja koja se bave suradljivošću adolescenata uglavnom govore o adherenciji u farmakološkom liječenju ${ }^{17}$.

\section{Suradljivost adolescenata ovisno o psihijatrijskom poremećaju i propisanim psihofarmacima}

Ghaziuddin i sur. (1999.) u jednom od prvih istraživanja o suradljivosti adolescenata pri liječenju psihofarmacima dobili su rezultate da je 66,2\% pacijenata surađivalo. Anketirali su 71 pacijenta ili njihove skrbnike šest do osam mjeseci nakon hospitalizacije. Većina ispitanih adolescenata patila je od depresivnih poremećaja (77,5\%), oko polovice od hiperkinetskog poremećaja $(56,3 \%)$ ili anksioznog poremećaja (45,7\%). Dobiveni postotci posljedica su i česte pojave komorbiditeta psihijatrijskih poremećaja. Autori zaključuju da je mali i relativno homogeni uzorak vjerojatni razlog zbog kojeg nisu pronašli razlike $u$ adherenciji ovisno o dijagnozi ${ }^{18}$. Pregledom dvanaest istraživanja adherencije mladih s hiperkinetskim poremećajima u uzimanju propisanih psihostimulansa dobiven je raspon adherencije od $35 \%$ do $100 \%{ }^{19}$. Istraživanja stopa adherencije mladih s bipolarnim afektivnim poremećajem pokazuju 
raspon od $33 \%$ do $84 \%^{20-23}$. Istraživanje Emilsson i sur. (2017.) provedeno nad 101 adolescentom s poremećajem hiperaktivnosti i deficitom pažnje (engl. attention deficit and hyperactivity disorder, ADHD), koji se liječe šest i više mjeseci, pokazalo je srednju suradljivost od $88 \%$ koristeći se MARS upitnikom (engl. Medication Adherence Report Scale) ${ }^{24}$. DelBello (2007.) nakon dvanaestomjesečnog praćenja 71 adolescenta u terapiji bipolarnog afektivnog poremećaja (BAP) bilježi punu suradljivost u $35 \%$ pacijenata. Isto istraživanje navodi da značajno niži stupanj suradljivosti imaju pacijenti koji uz BAP kao komorbiditet imaju ADHD ili zloupotrebu alkohola ${ }^{22}$. Gearing (2009.) je pratio adolescente nakon hospitalizacije zbog prve psihotične epizode i nakon 18 mjeseci suradljivo je bilo njih $75 \%$. Liječeni su novim (tzv. atipičnim) antipsihoticima i ova je stopa suradljivosti bolja od one dobivene u sličnim istraživanjima na odrasloj populaciji. Adolescenti koji su dobivali dodatnu farmakoterapiju za afektivne simptome (antidepresiv ili stabilizator raspoloženja) pokazali su deset puta veću adherenciju od onih koji su liječeni samo antipsihoticima. Ovako dobre rezultate može objasniti činjenica da je od ukupnog broja hospitaliziranih adolescenata samo $38 \%$ pristalo sudjelovati u istraživanju, stoga je teško zaključiti koja je stvarna stopa adherencije $\mathrm{e}^{25}$. King i sur. proveli su istraživanje sa 66 suicidalnih adolescenata. Šest mjeseci nakon hospitalizacije utvrđeno je da njih 66,7\% slijedi preporučenu farmakološku terapiju, 50,8 \% individualnu psihoterapiju, a samo $33,3 \%$ je bilo suradljivo u grupnoj psihoterapiji s obitelji ${ }^{26}$. Neka istraživanja navode da mladi s eksternaliziranim problemima ponašanja (agresivno ponašanje i delikvencija) surađuju lošije nego njihovi vršnjaci koji internaliziraju svoje probleme (povlačenje iz društva, anksioznost, depresivnost) ${ }^{16,27}$. Najznačajniji negativni utjecaj ima zloupotreba lijekova i droga, slijede komorbidno prisutni poremećaji u ponašanju (MKB dijagnoze pod šifrom F91, F92) i tzv. „dvostruka“ depresija (dugotrajno sniženo raspoloženje koje epizodično progredira do depresivne epizode $)^{28}$. Rizik od nesuradljivosti povećavaju određeni psihijatrijski simptomi, kao što su proganjajuće sumanutosti ili sumnjičavost te simptomi koji se teže liječe i duže traju ${ }^{28}$. Negati- van utjecaj također imaju genetski čimbenici i loša prognoza bolesti ${ }^{28}$.

Fontanella i sur. (2011.) ispitivali su pridržavanje liječenju antidepresivima i utvrdili da 49,5 \% mladih surađuje tijekom akutne faze bolesti, a samo $21 \%$ surađuje i tijekom faze održavanja ${ }^{29}$. Faza održavanja podrazumijeva nastavak liječenja istim antidepresivom u punoj dozi četiri do devet mjeseci nakon postizanja remisije ${ }^{30}$. Pacijenti koji primaju lijekove novijih generacija surađuju bolje od onih koji primaju lijekove starijih generacija, što se tumači boljim profilom nuspojava i jednostavnijim doziranjem novijih lijekova ${ }^{28}$. Fontanella je pokazao da upotreba drugih psihotropnih lijekova uz antidepresive poboljšava adherenciju pri liječenju ${ }^{29}$. Subdoziranje lijeka povećava rizik nesuradljivosti, a to je posebno izraženo u pacijenata s poremećajima raspoloženja. Očekivano je utvrđeno da pacijenti koji primaju lijekove per os (tablete, kapsule, kapi) imaju manji stupanj suradljivosti od onih koji primaju depotne pripravke intramuskularno, jer su depotni pripravci najčešće indicirani u slučaju nedovoljne suradnje u liječenju ${ }^{28}$.

\section{Suradljivost adolescenata ovisno o psihološkim čimbenicima}

Malobrojna su istraživanja koja ispituju subjektivne reakcije mladih na psihofarmakološko liječenje. Djeca i adolescenti često govore da im lijekovi pomažu, ali istovremeno izražavaju nenaklonost lijekovima i želju da ih izbjegnu ${ }^{16}$. Pozitivni učinci psihofarmaka koje adolescenti navode su bolja koncentracija, bolji školski ili akademski uspjeh, bolja samokontrola i više dobrih odnosa s drugim osobama. Razlozi zbog kojih ne vole uzimati lijekove su: sram ili strah od društvene stigme; nemaju potrebe za liječenjem; osjećaju da su „drugačiji“ ili da nisu nalik sebi dok ih uzimaju; smetaju im nuspojave i brinu se zbog mogućih dugoročnih učinaka lijeka ${ }^{16}$. Osjećaj stigmatiziranosti povezan sa psihijatrijskim liječenjem može biti posebno izražen u adolescenciji koju karakterizira naglašena samosvijest i želja za uklapanjem u društvo ${ }^{14,16}$. Scott i sur. (1992.) su u istraživanju adolescenata s poremećajima raspoloženja (afektivni poremećaji) ili psihotičnim poremećajima pronašli da $56 \%$ ispitanika osjeća potrebu za skri- 
vanjem svog stanja i liječenja od prijatelja ${ }^{31}$. Bowen i sur. (1991.) pronašli su da $27 \%$ adolescenata osjeća sram zbog uzimanja psihotropnih lijekova i taj sram bio je povezan s lošom adherencijom $^{32}$. S druge strane, Moses (2011.) je ustanovila da se $78 \%$ adolescenata ne osjeća stigmatizirano zbog uzimanja lijekova, no većina njenih ispitanika bila je u sustavu socijalne zaštite, gdje je uzimanje psihofarmaka češća pojava ${ }^{16}$. Dugotrajno liječenje može otežati razvoj autonomije u adolescenata. Neki adolescenti opisuju ne-

Metaanaliza pokazuje da mlađa dob, rasa, spol, struktura obitelji, potpora prijatelja, socioekonomski status, vrsta i vrijeme početka liječenja, simptomi i vlastiti osjećaji u vezi sa simptomima te povijest psihičkih simptoma ili bolesti ne utječu značajno na suradljivost adolescenata u psihijatrijskom liječenju.

lagodu zbog činjenice da ih se nadzire u uzimanju lijekova, smetaju im nametnuti pregledi i pretjerana zaštita koju čini obitelj. Drugi se boje da će postati ovisni o lijeku, čak i kada lijek suzbija psihičke simptome ${ }^{16}$. Adolescentova pozitivna uvjerenja i želja da se liječi čvrsto koreliraju s dobrom suradnjom, kao i prihvaćanje liječenja ${ }^{16,23,33,34}$. Manjak uvida u stvarnost i bolest je psihološki čimbenik koji najjače korelira s nesuradljivošću i najviše je istražen ${ }^{28}$. Ponekad uzrok nesuradljivosti leži u specifičnom kulturalnom ili religijskom poimanju bolesti i liječenja ${ }^{28}$. Verdoux i sur. (2002.) pokazali su da kognitivne funkcije nemaju bitan utjecaj na suradljivost ${ }^{35}$. Osjećaji bespomoćnosti, beznadnosti i niskog samopoštovanja, koji se često javljaju u depresiji, negativno utječu na suradljivost ${ }^{28}$. Isti utjecaj ima i povišeni stres, bio on samo percipiran ili stvaran ${ }^{28}$.

\section{Suradljivost adolescenata ovisno o utjecajima iz obitelji}

Obitelj je jedan od najznačajnijih čimbenika u postizanju suradnje psihijatrijski liječenih adolescenata. Adherencija u liječenju je veća ako su oba roditelja uključena u liječenje ${ }^{28}$. Munson i sur. (2010.) utvrdili su da viši prihodi roditelja pozitivno utječu na suradljivost adolescenta u farmakološkom i nefarmakološkom liječenju ${ }^{36}$.
Isto istraživanje pokazalo je i pozitivnu povezanost $s$ višim stupnjem obrazovanja i roditelja i adolescenta, što je naknadno potvrdila i Moses (2011.) u svom istraživanju ${ }^{16,36}$. Mladi smješteni u udomiteljskim obiteljima obično imaju veću adherenciju u usporedbi s onima koji žive sa svojim obiteljima ${ }^{29}$. Loša povezanost obitelji i neprilagodljivost povezane su s lošijom suradnjom ${ }^{16}$. Gau i sur. (2006.) pronašli su da je loša suradljivost u mladih s ADHD-om povezana s nemarnim odgojem, većom žalosti roditelja, majčinim zaštitničkim ponašanjem ili pretjeranom kontrolom, lošom potporom obitelji i manjkom razgovora djece s roditeljima ${ }^{19}$. Utvrđena je povezanost mentalne bolesti majke i loše adherencije adolescenta ${ }^{26}$.

U istraživanju Kinga i sur. (1997.) najznačajniji utjecaj na suradnju u obiteljskoj psihoterapiji pokazala je disfunkcionalnost obitelji, neuključenost oca, loš odnos oca i adolescenta, a majčini depresivni i paranoidni simptomi povezani su s lošom suradnjom u obiteljskoj i individualnoj psihoterapiji adolescenta ${ }^{26}$. Majčino protivljenje povezano je s lošijom adherencijom pri farmakoterapijii ${ }^{26}$. Negativni stavovi rodbine, odbijanje od strane obitelji ili visoka razina kriticizma jaki su čimbenici rizika za nesuradljivost i relaps bolesti28. ProtivIjenje obitelji ili prijatelja liječenju također ima negativan utjecaj na adherenciju adolescenata. Favre i sur. (1997.) ustanovili su da samo $20 \%$ rodbine pacijenata s prvom epizodom shizofrenije smatra lijekove potrebnima. Pacijenti imaju nižu adherenciju ako članovi obitelji ne žele biti uključeni u liječenje ili brigu oko pacijenta ${ }^{28}$.

\section{Suradljivost adolescenta ovisno o ostalim čimbenicima}

Gearing i Mian (2005.) u svom stručnom članku navode neke očekivane poveznice između suradljivosti adolescenta i liječnikovih osobina ili ponašanja. Lošije surađuju adolescenti koji imaju osjećaj da ih liječnici ne slušaju ${ }^{28,37-39}$, oni koji se ne slažu s liječnikom oko terapijskog plana, oni koji su negativno reagirali na hospitalizaciju ${ }^{28,39}$ ili su im troškovi liječenja neprihvatljivi ${ }^{28,40}$. Razumljivo, pacijenti koji nakon otpusta imaju dostupne kontrolne preglede te na njih dolaze, imaju i bolju adherenciju ${ }^{28,40-42}$.

Moses (2011.) navodi da su starija dob, muški spol i pripadnost etničkoj manjini relativno do- 
sljedno povezani s lošijom adherencijom ${ }^{16}$. No Timlin (2015.) to opovrgava nalazima metaanalize koja je obuhvatila 17 istraživanja objavljenih od 1990. do 2014. godine ${ }^{33}$. Metaanaliza pokazuje da mlađa dob, rasa, spol, struktura obitelji, potpora prijatelja, socioekonomski status, vrsta i vrijeme početka liječenja, simptomi i vlastiti osjećaji u vezi sa simptomima te povijest psihičkih simptoma ili bolesti ne utječu značajno na suradljivost adolescenata u psihijatrijskom liječenju ${ }^{33}$. Opća društvena podrška svojim porastom pozitivno korelira s boljom adherencijom, dok loša društvena podrška može pretkazivati lošu adherenciju ${ }^{28}$.

\section{Strategije za poboljšanje suradljivosti psihijatrijski liječenih adolescenata}

Za poboljšanje suradljivosti adolescenta mogu se koristiti metode kognitivne terapije kojima se nastoji promijeniti stavove i uvjerenja adolescenta ili njegove obitelji o liječenju. Neposredno bilježenje korisnih učinaka liječenja i nuspojava upitnicima može adolescente podsjetiti na ciljeve liječenja i potaknuti ih na bolju suradnju ${ }^{16}$. Istraživanje Bjørnholta i sur. (2016.) pokazalo je da podsjećanje adolescenata s psihijatrijskim poremećajima na uzimanje lijeka tekstnim porukama ne utječe bitno na suradljivost ${ }^{43}$. $U$ adolescenata koji se liječe od tjelesnih bolesti istraživanja pokazuju bolju suradljivost onih koji primaju podsjetnike tekstnim porukama od onih koji ih ne primaju ${ }^{44}$. Ovo se može objasniti pretpostavkom da oboljeli od tjelesnih bolesti češće nehotice zaboravljaju uzeti lijek, a oboljeli od psihijatrijskih poremećaja to češće čine namjerno, zbog nedostatka uvida.

Većina autora predlaže slične strategije za poboljšanje suradljivosti pacijenata, primjerice: razgovor s pacijentom o važnosti liječenja, davanje nagrada, edukacija i poboljšanje razumijevanja bolesti kod samog pacijenta i kod njegovih roditelja/skrbnika, korištenje ostalih zdravstvenih radnika u procesu edukacije poput medicinskih sestara, socijalnih radnika i liječnika obiteljske medicine. Iz navedenog proizlazi da je kontinuirana i sustavna edukacija svih zdravstvenih radnika važna za poboljšanje suradnje pacijenata. Uz ove raznolike tehnike, redoviti klinički pregledi i razgovori psihijatra i pacijenta također značajno mogu poboljšati suradljivost ${ }^{28,45}$.

\section{RASPRAVA}

Očekivani udio suradljivih pacijenata među psihijatrijski ili tjelesno liječenim adolescentima bitno se ne razlikuje ${ }^{3}$. Suradljivost odraslih psihijatrijskih pacijenata znatno varira ovisno o dijagnozi i režimu liječenja i ne postoje procjene suradljivosti općenito za sve psihijatrijske odrasle pacijente. Adolescenti oboljeli od BAP-a bilježe raspon suradljivosti između $33-84 \%^{20-23}$. U odraslih pacijenata s BAP-om Manwani i sur. (2007.) ustano-

U psihijatrijski liječenih adolescenata monoterapija često nije optimalna metoda liječenja.

Manjak uvida u bolest i u stvarnost je psihološki čimbenik koji najjače korelira s nesuradljivošću u psihijatrijski liječenog adolescenta.

vili su dobru suradljivost u 82,5\% pacijenata, a u skupini pacijenata koji su, uz BAP, zloupotrebljavali lijekove ili droge, zabilježen je stupanj suradljivosti od $65,5 \%{ }^{46}$. Ovakvi nalazi vrlo su širokog raspona te se ne može utvrditi postoji li razlika u suradljivosti adolescenata i odraslih oboljelih od BAP-a.

Suradljivost adolescenata od čak $75 \%$ bilježi se nakon hospitalizacije zbog prve psihotične epizo$\mathrm{de}^{25}$. U odraslih taj raspon varira između $56 \%$ i $67 \%{ }^{35,47}$. Ovu razliku moguće je objasniti činjenicom da adolescente najčešće roditelji ili skrbnici primoravaju na uzimanje lijekova i nadziru njihovu medikaciju.

DelBello (2007.) navodi zloupotrebu alkohola i droga kao čimbenik rizika za lošiju suradljivost psihijatrijski liječenih adolescenata ${ }^{22}$, a druga istraživanja potvrđuju isto za adolescente koji se liječe od tjelesnih bolesti ${ }^{48}$ i odrasle psihijatrijske pacijente ${ }^{46,49}$. Prema Kingu, suicidalni adolescenti pri uzimanju farmakoterapije surađuju u 66,7\% slučajeva, a u provođenju individualne psihoterapije u 50,8 $\%^{26}$. Fontanella tvrdi da adolescenti u akutnoj fazi liječenja antidepresivima surađuju u 49,5\%, u fazi održavanja $21 \%{ }^{29}$. Peveler i sur. su kod odraslih pacijenata liječenih antidepresivima otkrili da $40 \%$ prestaje uzimati lijekove do 12 . 
tjedna liječenja ${ }^{50}$. Prema dosadašnjim spoznajama, nema bitne razlike u suradnji između ovih skupina pacijenata.

Istraživanje Gearinga (2009.) sa psihotičnim adolescentima utvrdilo je deset puta bolju suradljivost kod onih koji su uz antipsihotike primali i lijekove za liječenje simptoma poremećaja raspoloženja (afektivni simptomi) ${ }^{25}$. Fontanella (2011.) $\mathrm{u}$ istraživanju suradljivosti depresivnih adolescenata nalazi da dodatna psihotropna medikacija, uz antidepresive, povećava njihovu suradljivost ${ }^{29}$.

Prepoznavanje depresivnih simptoma u svih skupina pacijenata važno je za sveukupni uspjeh liječenja, upravo zbog negativnog utjecaja tih simptoma na suradljivost.

Prema ovim rezultatima, u psihijatrijski liječenih adolescenata monoterapija često nije optimalna metoda liječenja. Ovi rezultati ističu važnost dobro i individualno skrojene farmakoterapije za postizanje dobre suradnje.

Hakim El Alama (2015.) navodi nuspojave kao rizični čimbenik za nesuradljivost u odraslih psihijatrijskih pacijenata ${ }^{51}$. Adolescenti od nuspojava kao razlog prekida terapije najčešće navode psihičke nuspojave, poput osjećaja da su „drugačiji“, da nisu nalik sebi, da ih lijekovi „otupljuju“16. Od tjelesnih nuspojava naglašavaju one koje utječu na njihov izgled ${ }^{29}$. Nedovoljno je istraživanja kojima bi se kvantificirao utjecaj nuspojava na suradljivost, stoga je nepoznato postoje li razlike između adolescenata i odraslih pacijenata. Više je istraživanja koja ukazuju da osjećaji srama i stigmatiziranosti negativno utječu na suradnju adolescenata ${ }^{31-33}$. Rezultati ne ukazuju na postojanje razlike između adolescenata i odraslih psihijatrijskih pacijenata vezano uz negativni utjecaj stigme na suradnju ${ }^{14}$. Pozitivan utjecaj na suradljivost adolescenata imaju njihova pozitivna uvjerenja, želja da se podvrgnu liječenju te prihvaćanje liječenja ${ }^{16,23,33,34}$. Ovo odgovara rezultatima istraživanja na uzorku odraslih psihijatrijskih pacijenata9,52. Isto se pokazalo i kod adolescenata koji se liječe od tjelesnih bolesti ${ }^{48}$. Manjak uvida u bolest i u stvarnost je psihološki čimbenik koji najjače korelira s nesuradljivošću u psihijatrijski liječenog adolescen$\mathrm{ta}^{28,40,42,53-55}$. U tjelesno liječenih adolescenata nađeno je da nijekanje postojanja bolesti i njeno nerazumijevanje također smanjuje suradljivost ${ }^{56}$. Istraživanje provedeno nad odraslim pacijentima koji boluju od shizofrenije pokazalo je da oni koji imaju dobar uvid imaju i bolju suradljivost ${ }^{57}$.

Osjećaj bespomoćnosti, beznadnosti i smanjeno samopoštovanje negativno utječu na suradljivost adolescenata u psihijatrijskom liječenju ${ }^{28}$. Tjelesno liječeni adolescenti koji imaju iste te osjećaje ili dijagnosticiranu depresiju također lošije surađuju ${ }^{48}$. Pronađeno je i da među odraslim psihijatrijskim pacijentima lošije surađuju depresivni ${ }^{9}$. Može se zaključiti da ovaj negativni utjecaj postoji bez obzira na dob i bolest zbog koje se osoba liječi. Prepoznavanje depresivnih simptoma u svih skupina pacijenata važno je za sveukupni uspjeh liječenja, upravo zbog negativnog utjecaja tih simptoma na suradljivost.

Istraživanja potvrđuju važnost obiteljske bliskosti i potpore u psihijatrijskom liječenju adolescenata, kao i pri liječenju adolescenata od tjelesnih bolesti ${ }^{16,28,48}$. U skupini odraslih psihijatrijskih pacijenata, oni koji su u braku pokazuju bolju suradljivost od samaca, rastavljenih i udovaca ${ }^{50}$. Sve skupine pacijenata pokazuju pozitivan odnos između dobre suradljivosti i pozitivnog i dobrog terapijskog saveza, uvjerenja liječnika u učinkovitost tretmana te dostupnih kontrolnih pregleda ${ }^{7,28,48,51}$. $U$ adolescenata se za poboljšanje suradljivosti mogu koristiti strategije kognitivne psihoterapi$\mathrm{je}^{58}$. Za odrasle psihijatrijske pacijente slične metode su se također pokazale učinkovitima u poboljšanju suradljivosti ${ }^{59}$. Nema naznaka za postojanje bitnih razlika između odraslih pacijenata i adolescenata.

Mjerenje suradljivosti zahtjevno je u svim populacijama, a rezultati ovise o odabranoj metodi, trajanju mjerenja, obilježjima uzorka i drugim čimbenicima ${ }^{33}$. Većina istraživanja rađena je na relativno malim uzorcima. Zbog svega navedenog rezultati istraživanja jako variraju i interpretacija rezultata je dvojbena ${ }^{18}$.

\section{ZAKLJUČAK}

Na suradnju psihijatrijski liječenih adolescenata negativno utječu osjećaj stigmatiziranosti, osjećaj da ih se kontrolira, manjak uvida u stvarnost i bolest te bespomoćnost i beznađe. Pozitivno utječu 
pozitivna uvjerenja adolescenta, želja da se liječi i prihvaćanje liječenja, potpora roditelja i obitelji, dobar odnos i komunikacija adolescenta i liječnika. Rezultati istraživanja utjecaja različitih demografskih čimbenika su nedosljedni. Dosadašnja istraživanja ne ukazuju na postojanje bitne razlike između suradljivosti psihijatrijski liječenih adolescenata, adolescenata liječenih od tjelesnih bolesti i odraslih psihijatrijskih pacijenata. Izuzetak su adolescenti liječeni od prve psihotične epizode, čija je suradnja bolja u odnosu na istu skupinu odraslih pacijenata. Neki nalazi sugeriraju da monoterapija često nije najbolja metoda za postizanje dobre suradnje psihijatrijski liječenih adolescenata. Zbog mogućih dugoročnih negativnih posljedica nesuradljivosti na život adolescenta, kao i na cjelokupni zdravstveni sustav, nužna su daljnja istraživanja ove problematike.

Izjava o sukobu interesa: Autori izjavljuju da ne postoji sukob interesa.

\section{LITERATURA}

1. Ivančević Ž. MSD priručnik dijagnostike i terapije. 18. izdanje. Split: Placebo d. o. o., 2010.

2. Anon. Compliance - a broken concept. BMJ 1997;314:1.

3. Sabate E. Adherence to long-term therapies: Evidence for action. 1st ed. Geneva: World Health Organization, 2003.

4. Jimmy B, Jose J. Patient Medication Adherence: Measures in Daily Practice. Oman Med J 2011;26:155-9.

5. Mullen PD. Compliance becomes concordance. BMJ 1997;314:691-2.

6. Francetić I, Vitezić D. Klinička farmakologija. 2. izdanje. Zagreb: Medicinska naklada, 2014.

7. Čulig J. Adherencija prema propisnoj farmakoterapiji. Pharmabiz 2016;22:44-7.

8. Haynes RB, McDonald H, Garg A, Montague P. Interventions for helping patients to follow prescriptions for medications. Cochrane Database Syst Rev 2002; CD000011.

9. Bahrini L, Damak R, Cheour M. The role of the affective temperament in the treatment adherence in psychiatry. Pan Afr Med J 2016;25:2.

10. Blondiaux I, Alagille M, Ginestet $D$. Adhésion aux traitements biologiques en psychiatrie. Encycl Méd Chir 1994:1-3.

11. Cybermed.hr [Internet] Folnegović Šmalc V. Važnost suradljivosti psihičkih bolesnika u uzimanju lijekova. c2015 [cited 2018 Apr 14] Available from: http://www.cybermed.hr/clanci/vaznost_suradljivosti_psihickih_ bolesnika_u_uzimanju_lijekova.

12. Stockwell Morris L, Schulz RM. Patient compliance - an overview. J Clin Pharm Ther 1992;17:283-95.

13. Lam WY, Fresco P. Medication adherence measures: an overview. Biomed Res Int 2015;2015:217047.

14. Taddeo D, Egedy M, Frappier JY. Adherence to treatment in adolescents. Paediatr Child Health 2008;31:19-24.
15. Graovac M. Adolescent u obitelji. Med Flum 2010;46(3): 261-6.

16. Moses T. Adolescents' commitment to continuing psychotropic medication: a preliminary investigation of considerations, contradictions, and correlates. Child Psychiatry Hum Dev 2011;42:93-117.

17. Timlin U, Hakko H, Riala K, Rasanen P, Kyngas H. Adherence of $13-17$ year old adolescents to medical and non-pharmacological treatment in psychiatric inpatient care: special focus on relative clinical and family factors. Child Psychiatry Hum Dev 2015;46:725-35.

18. Ghaziuddin N, King CA, Hovey JD, Zaccagnini J, Ghaziuddin M. Medication noncompliance in adolescents with psychiatric disorders. Child Psychiatry Hum Dev 1999;30: 103-10.

19. Gau SSF. Determinants of adherence to methylphenidate and the impact of poor adherence on maternal and family measures. J Child Adol Psychop 2006;16:286-97.

20. Drodar D. Adherence to pharmacological treatment for juvenile bipolar disorder. J Am Acad Child Psychiatry 2007;46:831-9.

21. Coletti DJ, Leigh E, Gallelli KA, Kafantaris V. Patterns of adherence to treatment in adolescents with bipolar disorder. J Child Adol Psychop 2005;15:913-7.

22. DelBello MP, Hanseman D, Adler CM. Twelve-month outcome of adolescents with bipolar disorder following first hospitalization for a manic or mixed episode. Am J Psychiatry 2007;164:582-90.

23. Patel NC, DelBello MB, Keck PE, Strakowski SM. Ethnic differences in maintenance antipsychotic prescription among adolescents with bipolar disorder. J Child Adol Psychop 2005;15:938-46.

24. Emilsson M, Gustafsson PA, Öhnström G, Marteinsdottir I. Beliefs regarding medication and side effects influence treatment adherence in adolescents with attention deficit hyperactivity disorder. Eur Child Adolesc Psychiatry 2017;26:559-71.

25. Gearing RE, Charach A. Medication adherence for children and adolescents with first-episode psychosis following hospitalization. Eur Child Adolesc Psychiatry 2009;18:587-95.

26. King CA, Hovey JD, Brand E, Wilson R, Ghaziuddin N. Suicidal adolescents after hospitalization: parent and family impacts on treatment follow-through. J Am Acad Child Adolesc Psychiatry 1997;36:85-93.

27. Nunes, SAN Faraco AMX, Vieira ML, Rubin KH. Externalizing and internalizing problems: contributions of attachment and parental practices. Psicologia: Reflexao e Critica 2013;26:617-25.

28. Gearing RE, Mian IA. An Approach to Maximizing Treatment Adherence of Children and Adolescents with Psychotic Disorders and Major Mood Disorders Can Child Adolesc Psychiatr Rev 2005;14:106-13.

29. Fontanella CA, Bridge JA, Marcus SC, Campo JV. Factors associated with antidepressant adherence for Medicaidenrolled children and adolescents. Ann Pharmacoth 2011;45:898-908.

30. Psychistryonline.org [Internet] Gelenberg AJ, Freeman MP, Markowitz JC, Rosenbaum JE. Practice guidelines for the treatment of patients with major depressive disorder. 3rd ed. American Psychiatric Association, c2010. [cited 2018 May 15] Available from: https:// psychiatryonline.org/pb/assets/raw/sitewide/practice_ guidelines/guidelines/mdd.pdf. 
31. Scott C, Lore C, Owen R. Increasing medication compliance and peer support among psychiatrically diagnosed students. J Sch Health 1992;62:478-80.

32. Bowen J, Fenton T, Rappaport L. Stimulant medication and attention deficit-hyperactivity disorder. J Dis Child 1991;145:291-5.

33. Timlin $U$, Hakko $H$, Heino $R$, Kyngas $H$. Factors that affect adolescent adherence to mental health and psychiatric treatment: a systematic integrative review of the literature. Scand J Child Adolesc Psychiatr Psychol 2015;3:99-107.

34. Pogge DL, Singer MB, Harvey PD. Rates and predictors of adherence with atypical antipsychotic medication: A follow-up study of adolescent inpatients. J Child Adolesc Psychopharmacol 2005;15:901-12.

35. Verdoux H, Liraud F, Assens F, Abalan F, van Os J. Social and clinical consequences of cognitive deficits in early psychosis: a two-year follow-up study of first-admitted patients. SchizophrRes 2002;56:149-59.

36. Munson MR, Floerch JE, Townsend L. Are health beliefs related to adherence among adolescents with mood disorders? Adm Policy Ment Health 2010;37:408-16.

37. Bordenave-Gabriel C, Giraud-Baro E, De Beauchamp I, Bougerol T, Calop J. Why psychotic patients are not drug compliant?. Encephale 2003;29:213-22.

38. Pope M, Scott J. Do clinicians understand why individuals stop taking lithium? J Affect Disord 2003;74:287-91.

39. Sayre J. The patient's diagnosis: Explanatory models of mental illness. Qual Health Res 2000;10:71-83.

40. Sullivan G, Wells KB, Morgenstern H, Leake B. Identifying modifiable risk factors for rehospitalization: A case-control of seriously mentally ill persons in Mississippi. Am J Psychiatry 1995;152:17491756.

41. Caton CLM, Goldstein JM, Serrano O, Bender R. The impact of discharge planning on chronic schizophrenic patients. Hosp Community Psychiatry 1984;35:255-62.

42. Robinson DG, Woerner MG, Ma J, Alvir J, Binder RM, Hinrichsen GA et al. Predictors of medication discontinuation by patients with first-episode schizophrenia and schizoaffective disorder. Schizophr Res 2002;57:209-19.

43. Bjornholt K, Christiansen E, Stokholm KA, Hvolby A. The effect of daily small text message reminders for medicine compliance amongst young people connected with the outpatient department for child and adolescent psychiatry. A controlled and randomized investigation. Nord J Psychiatry 2016;70:285-9.

44. Branson CE, Clemmey P, Mukherjee P. Message reminders to improve outpatient therapy: attendance among adolescents: a pilot study. Psychol Serv 2013;10:298-303.

45. Greydanus DE, Kaplan G. Strategies to improve medication adherence in youths. Psychiatric Times 2012;29:1-2.
46. Manwani SG, Szilagyi KA, Zabottsky B, Hennen J, Griffin $\mathrm{ML}$, Weiss RD. Adherence to pharmacotherapy in bipolar disorder patients with and without co-occurring substance use disorders. J Clin Psychiatry 2007;68:1172-6.

47. Verdoux $\mathrm{H}$, Lengronne J, Liraud F. Medication adherence in psychosis: predictors and impact on outcome. A 2-year follow-up of first-admitted subjects. Acta Psychiatr Scand 2000;102:203-10.

48. Staples B, Bravender T. Drug compliance in adolescents: assessing and managing modifiable risk factors. Pediatr Drugs 2002;4:503-13.

49. Jonsdottir H, Opjordsmoen S, Birkenaes AB et al. Predictors of medication adherence in patients with schizophrenia and bipolar disorder. Acta Psychiatr Scand 2012; 127:23-33.

50. Peveler R. Effect of antidepressant drug counselling and information leaflets on adherence to drug treatment in primary care: randomised controlled trial. BMJ 1999; 319:612-5.

51. El Alama H, Benmoussa A, Said AAH. Assessment of therapeutic adherence among patients in psychiatry. Int J Phytopharmacol 2015;5:27-32.

52. Bollini P, Tibaldi G, Testa C, Munizza C. Understanding treatment adherence in affective disorders: a qualitative study. J Psychiatr Ment Health Nurs 2004;45:668-74.

53. Bergen J, Hunt G, Armitage P, Bashir M. Sixmonth outcome following a relapse of schizophrenia. Aust N Z J Psychiatry 1998;32:815-22.

54. Mutsatsa SH, Joyce EM, Hutton SB, Webb E, Gibbins H, Paul S, Barnes TR. Clinical correlates of early medication adherence: West London first episode schizophrenia study. Acta Psychiatr Scand 2003;108:439-46.

55. Olfson, M, Mechanic D, Boyer CA, Hansell S. Linking inpatients with schizophrenia to outpatient care. Psychiatr Serv 1998;49:911-7.

56. Adler LD, Nierenberg AA. Review of medication adherence in children and adults with ADHD. Postgrad Med J 2010;122:184-91.

57. Na E, Yim SJ, Lee JN, Kim JM, Hong K. Relationship among medication adherence, insight, and neurocognition in chronic schizophrenia. Psychiatry Clin Neurosci 2015;69:298-304.

58. The TADS Team. The treatment for adolescents with depression study (TADS): long- term effectiveness and safety outcomes. Arch Gen Psychiatry 2007;64:113244.

59. Velligan DI, Weiden PJ, Sajatovic M, Scott J, Carpenter D, Ross R. The expert consensus guideline series: adherence problems in patients with serious and persistent mental illness. J Clin Psychiatry 2009;70:1-46. 